\title{
Mini-review: clinical and molecular markers in early diabetic nephropathy
}

\begin{abstract}
Diabetes mellitus (DM) is the sixth leading cause of death worldwide because of its complications. One of these deadly complications is diabetic nephropathy, the leading cause of end-stage renal disease in the western world. Despite the worldwide acceptance to use albumin-to-creatinine $(\mathrm{A} / \mathrm{C})$ ratio and estimated glomerular filtration rate (eGFR) in clinical settings, there is no trustable and valid biochemical marker that can sensitively detect early stages of diabetic nephropathy. Therefore the early detection of the deterioration in kidney function and the changes in kidney structure before the albumin level becomes significantly high in urine is very important for patient's life. The aim of this review is to summarize some novel clinical and molecular markers being investigated as potential candidates to fill in the gap.

Keywords: early stage, molecular markers, clinical markers, mi-RNA, urinary proteome, kidney
\end{abstract}

Volume 2 Issue 3 - 2018

\author{
Mohamed Reda, Hatem K Amin \\ Department of biochemistry and molecular biology, Helwan \\ University, Egypt
}

\begin{abstract}
Correspondence: Mohamed Reda, Department of biochemistry and molecular biology, Helwan University, Egypt, Tel 0020-1028686439,
\end{abstract}

Email mohamed_abdelaal@pharm.helwan.edu.eg

Received: April 03, 2018 | Published: May 14, 2018
Abbreviations: IDF, international diabetes federation; DM, diabetes mellitus; DN, diabetic nephropathy; GFR, glomerular filtration rate; ESRD, end-stage renal disease; MDRD, modification of diet in renal disease

\section{Introduction}

Diabetes Mellitus (DM) is now seen as one of the strongest enemies we have to defeat. Despite our efforts and newly developed weapons, the current estimation of total diabetes population is 425 million people in the world and unlikely, it is estimated that by 2045 around 438 million people aged 20-64 years old will be diagnosed with diabetes. ${ }^{1}$ According to the International Diabetes Federation (IDF), Egypt is ranked as the $8^{\text {th }}$ country for the number of adults with diabetes (20-79 years) and for their healthcare expenditure. According to $\mathrm{WHO}$, the prevalence of type 2 diabetes in Egypt was almost tripled over the last two decades. By 2030, it is estimated that the number of Egyptians with DM will rise to 6,726,000. In terms of etiology, DM occurs as a result of either insulin deficiency or insulin resistance. Consequently, DM has two main types: type 1 and type 2. DM is characterized by hyperglycemia, which is the primary cause of most complications seen in patients such as nephropathy and endothelial dysfunction. ${ }^{2,3}$ Diabetic nephropathy (DN) is one of the most common complications of DM. DN is a progressive renal disease caused by alterations in tubular and glomerular structure and function. These alternations include basement membrane thickening in the glomerulus and tubules, accumulation of the components of extracellular matrix, detachment of podocytes from glomerular basement membrane, hyperplasia of mesangial cells and thickening of mesangial matrix. These pathological changes are usually induced by the rise in blood glucose level. ${ }^{4,5}$ Major advances have been made over the past few decades in diagnosing and treating patients with DN however, we are still unable to increase the survival rates among these patients. ${ }^{6} \mathrm{DN}$ is considered to be the leading cause of end-stage renal disease (ESRD) in the Western world representing about $50 \%$ of cases. It is characterized by albuminuria (urine albumin/creatinine ratio is $>300 \mathrm{mg} / \mathrm{g}$ ), and/or a glomerular filtration rate (GFR) below $60 \mathrm{~mL} / \mathrm{min} / 1.73 \mathrm{~m}^{2} .^{7,8}$ Novel well-validated biomarkers, when used in combination with conventional biomarkers, can efficiently clarify the pathophysiology of DN and can accurately stratify DN patients based on their disease stage. This will help finally in tailoring the appropriately personalized mediations for each one of these patients. To detect the early stages of diabetic nephropathy, there are many recently-investigation biomarkers that can be tracked in blood or urine.

\section{Discussion}

\section{Definition of biomarkers}

Biomarkers could be defined as "characteristics which are objectively measured and evaluated so as to indicate pathogenic processes, normal biochemical processes, or therapeutic responses to a certain drug".

\section{Current status of DN biomarkers}

Renal biopsy is known to be the gold standard for definitive and affirmed diagnosis of DN; however, because it is an invasive procedure it is now conserved for diagnosis confirmation. The diagnosis is now based on measuring the level of albumin in urine as well as on estimating the GFR. Current guidelines state that both parameters have to be measured, at least once a year, in order to diagnose, screen for or monitor DN. ${ }^{10}$ Estimated GFR (eGFR) is calculated using creatinine levels measured in patient's serum. There are some formulae that are now available to estimate eGFR, for example, Chronic Kidney Disease Epidemiology Collaboration (CKD-EPI) tool and the Modification of Diet in Renal Disease (MDRD) study equation. ${ }^{11,12}$

\section{Limitations of using eGFR and $\mathrm{A} / \mathrm{C}$ ratio}

There are a number of reasons why eGFR is considered to have "limited use" for early diagnosis of DN; the level of creatinine in blood is highly affected by muscle mass so the use of eGFR in obese or malnourished persons will give hesitated results. ${ }^{13}$ Second, the estimation of GFR is considered to be less accurate so eGFR won't be able to accurately predict the early stages of DN. Finally, the accuracy of the two previously mentioned formula is low in patients with diabetes mellitus. ${ }^{14}$ Similarly A/C ratio isn't the ideal biomarker to be measured for the early detection of DN. The following observations 
will clarify the reasons; it was reported that there are some phenotypes of DN with neither microalbuminuria nor reduced eGFR..$^{15-17}$ Second, the level of albumin in urine was found to be independently related to the risk of renal or cardiovascular complications. ${ }^{18}$ Finally, Longterm studies on patients with diabetes revealed that it isn't necessary that patients with microalbuminuria will proceed to overt $\mathrm{DN}$ because many of these patients, by time, became normoalbuminuric again. ${ }^{19,20}$

\section{Novel biomarkers that can be potentially used in the early detection of DN}

Because of the previously-mentioned limitations for both $\mathrm{A} / \mathrm{C}$ ratio and eGFR, there are a lot of biomarkers now under investigation for the potential use as indicators for early-stage DN. The pathogenesis of DN was found to be somehow complex. Consequently, there would be multiple biomarkers that appear in blood and urine and can be tracked in both of them. This observation led to the development of some diagnostic approaches for "multimarker" analysis so that the specificity and sensitivity of detection can be increased and/or improved. ${ }^{21-35}$

\section{Clinical biomarkers}

By extracting and refining the literature over the last decade, it was found that most of the clinical biomarkers being investigated are proteins in nature, some of them are demonstrated in Table 1 shows examples of the recently-investigated clinical biomarkers which can be potentially used in the detection of early stages of DN or in the monitoring of $\mathrm{DN}$ in some situations.

Table I Summary of some proteins that were found to be associated with DN

\begin{tabular}{|c|c|c|c|c|c|}
\hline Biomarker & Isolated From & Type of DM & Reference & Conclusion & Comment(S) \\
\hline $\begin{array}{l}\mathrm{Cu}-\mathrm{Zn} \text { superoxide } \\
\text { dismutase }(\mathrm{SOD})-1\end{array}$ & $\begin{array}{l}\text { Kidney lysate of an } \\
\text { STZ-induced rat } \\
\text { model of DN }\end{array}$ & NA* & 23 & $\begin{array}{l}\text { The study stated that the expression of } \\
\text { SOD-1 was reduced in streptozotocin } \\
\text { (STZ)-induced rats in comparison } \\
\text { to normal rats. These changes in } \\
\text { expression appeared prior to detectable } \\
\text { microalbuminuria }\end{array}$ & $\begin{array}{l}\text { Lacking the same } \\
\text { investigation on human } \\
\text { samples. }\end{array}$ \\
\hline $\begin{array}{l}\text { Urinary epidermal } \\
\text { growth factor } \\
\text { (uEGF) }\end{array}$ & Human urine & Type 2 DM & 24 & $\begin{array}{l}\text { Low uEGF-to-creatinine ratio was found } \\
\text { to be associated with the decline in renal } \\
\text { function in patients with normoalbuminuria } \\
\text { so it can then be used as a novel early } \\
\text { marker of DN }\end{array}$ & Small sample size \\
\hline $\begin{array}{l}\text { Inositol } \\
\text { pentakisphosphate } \\
\text { 2-kinase (IPP2K), } \\
\text { zona occludens } \\
\text { 3, and FAT tumor }\end{array}$ & Human urine & Type 1 DM & 25 & $\begin{array}{l}\text { These markers have a correlation with } \\
\text { early renal function decline so they are } \\
\text { considered good candidates for use as } \\
\text { sensitive biomarkers in clinical settings. }\end{array}$ & $\begin{array}{l}\text { The study mentioned that } \\
\text { validation studies are } \\
\text { needed for these biomarkers } \\
\text { using large populations. }\end{array}$ \\
\hline
\end{tabular}

suppressor 2

Good et al. ${ }^{26}$ developed a classifier which functions through categorizing patients with CKD, based on the status of 273 predetermined peptides in comparison to a healthy control, with high sensitivity and specificity. While, Zürbig et al. ${ }^{27}$ demonstrated that previously generated CKD273 classifier can identify patients with normoalbuminuria, that will develop diabetic nephropathy during a 5-year follow-up

There is a concomitant increase in the plasma levels of CHIT1 with albuminuria in patients having T2D. So, CHIT1 represents a promising and noninvasive tool for the evaluation of $\mathrm{DN}$
It is highly recommended to up-scale the application of the classifier thus it can be used routinely in clinical practice.

$\begin{array}{lll}\text { Chitotriosidase } & \text { Human plasma } & \text { Type } 2 \text { DM }\end{array}$

This meta-analysis of several studies concluded that elevated TGF- $\beta$ level in the serum of patients with diabetes is associated with a high risk of DN.
Further research is needed to support this point.
TGF- $\beta 1$

Human serum

Type 2 DM 
Table Continued

$\begin{array}{llll}\text { monocyte/ } & \text { kidney lysate of } & \\ \text { neutrophil elastase } & \text { OVE26 transgenic } & \text { Type 1 DM } & 30 \\ \text { inhibitor } & \text { mouse model(1) } & \end{array}$

Ceruloplasmin, transferrin, and prostate stem cell antigen

E-cadherin and urinary soluble fragment of E-cadherin (sEcadherin)
The decrease in elastase inhibitor-toelastase ratio in the OVE26 mice causes an increase in the rate of deposition of elastin in renal tubules and the interstitium. This means that expression of elastase inhibitor Lacking the same investigation on human samples. is correlated to $\mathrm{DN}$ in diabetic mice.

These proteins, plus other proteins, were significantly increased in microalbuminuric vs normoalbuminuric patients with type 2 diabetes

This protein was found to be upregulated in microalbuminuric vs DM and control patients. The sE-cadherin-to-creatinine ratio was significantly increased in microalbuminuric and macroalbuminuric patients vs normoalbuminuric and control groups

One study has concluded that haptoglobinto-creatinine ratio can be used as a predictor for ESRD in microalbuminuric patients. ${ }^{33}$ However, in another study, no significant difference was found between patients with DN and those with noncomplicated DM. ${ }^{34} \mathrm{~A}$ third study found that there is no significant correlation between different genotypes of haptoglobin and risk of overt DN. ${ }^{35}$
Further studies are needed to alleviate this conflict.

*NA= not available (I)The OVE26 mouse is a model of type I DM, with a deficient production of insulin, as a result of transgenic overexpression of calmodulin in pancreatic $\beta$ cells. ${ }^{36}$

\section{Molecular biomarkers}

\section{Micro RNAs associated with DN}

Major pathophysiological alternations of DN include expansion of the glomerular mesangium, podocyte dysfunction; which results in proteinuria, and also glomerular basement membrane thickening and tubulointerstitial fibrosis caused by the accumulation of extracellular matrix (ECM) proteins. ${ }^{37,38}$ MiRNAs are short non-coding RNAs that consist of about 20-22 nucleotides. They were found to play an important role in mammalian gene expression through suppressing translation process, inducing mRNA degradation and consequently stages of DN

\begin{tabular}{|c|c|c|c|c|c|}
\hline Biomarker & $\begin{array}{l}\text { Isolated } \\
\text { From }\end{array}$ & Type of DM & Study & Conclusion & Our comment(S) \\
\hline $\operatorname{miR}-377$ & Human urine & Type 1 DM & 41 & $\begin{array}{l}\text { In this recent clinical study, it was found that urinary } \\
\text { excretion of miRNA } 377 \text { was significantly higher in } \\
\text { microalbuminuric patients than normoalbuminuric } \\
\text { patients and healthy controls. These results suggest } \\
\text { that miR-377 can be used as an early biomarker for } \\
\text { nephropathy in pediatric type } 1 \text { diabetes }\end{array}$ & $\begin{array}{l}\text { The next step is to measure } \\
\text { miR-377 on a large population } \\
\text { and to develop a validated } \\
\text { protocol that can be used in } \\
\text { the clinical practice for the } \\
\text { assessment of DN cases. }\end{array}$ \\
\hline miRNA-216a & Human urine & Type $1 \mathrm{DM}$ & 41 & $\begin{array}{l}\text { MiR-216a was negatively correlated to } \mathrm{HbA} 1 \mathrm{C} \text { and } \\
\text { urinary albumin-to-creatinine ratio (UACR). These } \\
\text { results suggest that miR-216a can be used as an } \\
\text { early biomarker for nephropathy in pediatric type } 1 \\
\text { diabetes }\end{array}$ & $\begin{array}{l}\text { We recommend to measure } \\
\text { this marker on larger sample } \\
\text { size and to develop a validated } \\
\text { protocol that can be used in } \\
\text { the clinical practice for the } \\
\text { assessment of DN cases. }\end{array}$ \\
\hline Biomarker & $\begin{array}{l}\text { Isolated } \\
\text { From }\end{array}$ & Type of DM & Study & Conclusion & Our comment(S) \\
\hline
\end{tabular}

silencing the gene. ${ }^{39,40}$ Different miRNA were found to be involved in the development and progression of the pathophysiological alternations associated with DN. This means that we can detect certain types of miRNAs which are specific for the tissues exhibiting alternations in their structure and/or function as a result of hyperglycemia-related complications. Number of miRNAs were found in literature that were well-studied by researchers and were summarized in Table 2 .

Table 2 miR-377, miRNA-2I6a, miR-2I and miR-192 are examples of the recently-nvestigated mi RNAs that can be used in the detection of early 
Table Continued

\begin{tabular}{|c|c|c|c|c|c|}
\hline miR-21 & $\begin{array}{l}\text { Cultured } \\
\text { mesangial } \\
\text { cells from } \\
\text { diabetic } \mathrm{db} / \mathrm{db} \\
\text { mice }\end{array}$ & NA* & $42-43$ & $\begin{array}{l}\text { The over expression of miR- } 21 \text { inhibited proliferation } \\
\text { of mesangial cells in diabetic } \mathrm{db} / \mathrm{db} \text { mice. miR- } 21 \\
\text { expression was found to be down regulated in early } \\
\text { DN in vitro and in vivo suggesting that it can be used } \\
\text { as an early biomarker of DN. }\end{array}$ & $\begin{array}{l}\text { We recommend measuring the } \\
\text { level of miRNA- } 21 \text { in human } \\
\text { urine and relating its level to } \\
\text { UACR. }\end{array}$ \\
\hline miR-192 & $\begin{array}{l}\text { Kato et al. } \\
\text { used renal } \\
\text { cortex of WT } \\
\text { STZ-diabetic } \\
\text { and } \mathrm{db} / \mathrm{db} \\
\text { mice. Ma et } \\
\text { al. isolated } \\
\text { the mi RNA } \\
\text { from human } \\
\text { urine }\end{array}$ & NA* & 44-46 & $\begin{array}{l}\text { MiR-192 levels were increased significantly in } \\
\text { glomeruli isolated from streptozotocin-injected } \\
\text { diabetic mice as well as in diabetic db/db mice } \\
\text { in comparison to control mice without diabetes. }{ }^{44} \\
\text { Another study proved that the expression of } \\
\text { miR-192 was negatively correlated with UACR. }{ }^{45} \\
\text { It was suggested by another study that inhibition of } \\
\text { miR-192 expression may be an approach to slow } \\
\text { down the pathogenesis of DN. }{ }^{46}\end{array}$ & $\begin{array}{l}\text { The scope now should be } \\
\text { focused on the development of } \\
\text { a validated protocol which can } \\
\text { be used in the clinical practice } \\
\text { for the assessment of DN cases } \\
\text { and alleviate the contradictory } \\
\text { correlation with UACR test. }\end{array}$ \\
\hline
\end{tabular}

\section{*NA= not available}

\section{Conclusion}

Urinary proteomics has a wide applicability in differentiating individuals with normoalbuminuria and risk factors for developing DN from those with stable renal function. Urinary proteomics also can be used to detect patients with a decline in renal function despite being normoalbuminuric. ${ }^{23,24,28}$ It seems that Urinary epidermal growth factor (uEGF), inositol pentakisphosphate 2-kinase (IPP2K), zona occludens 3, FAT tumor suppressor 2 and $\mathrm{Cu}-\mathrm{Zn}$ superoxide dismutase (SOD)-1, specifically, have a significant association with the early stages of DN thus they are potential biomarkers for early diabetic nephropathy. ${ }^{23-25}$ It was shown in the mentioned studies that the expression level of mi RNAs in tissues, especially those with pathological alternations in their structure and/or function can be detected and correlated to the pathophysiology of these alternations. When these alternations result from hyperglycemia-induced complications, the changes in miRNA levels can be then correlated to the pathophysiology of the disease. We recommend that the future research should focus on tracking miR-377, miRNA-216a and miR-21 in human urine in phase 3 clinical trials recruiting large DN populations and also focus on the development of validated protocols for using these biomarkers in the detection of early DN in clinical practice.

\section{Acknowledgments}

None.

\section{Conflict of interest}

Author declares that there is no conflict of interest.

\section{References}

1. Suvi Karuranga, Jda RF, Yadi Huang, et al. International Diabetes Federation, IDFAtlas. Brussels. 2017.

2. El-Sayed, M-IK, Amin HK. Mechanism of endothelial cytoprotective and thrombo-resistance effects of sildenafil, vardenafil and tadalafil in male rabbit. Arch Med Sci. 2015;11(1):190-198.

3. El-Baky AE, Amin HK. Effect of citrullus colocynthis in ameliorate the oxidative stress and nephropathy in diabetic experimental rats. International Journal of Pharmaceutical Studies and Research. 2011;2(2):1-10.

4. Pourghasem M, Shafi H, Babazadeh Z. Histological changes of kidney in diabetic nephropathy. Caspian journal of internal medicine. 2015;6(3):120-127.

5. Berkman J, Rifkin H. Unilateral nodular diabetic glomerulosclerosis (Kimmelstiel-Wilson): report of a case. Metabolism clinical and experimental. 1973;22(5):715-722.
6. Campion CG, Sanchez-Ferras O, Batchu SN. Potential Role of Serum and Urinary Biomarkers in Diagnosis and Prognosis of Diabetic Nephropathy. Canadian journal of kidney health and disease. 2017.

7. Collins AJ, Foley RN, Herzog C, et al. US Renal Data System 2012 Annual Data Report. American Journal of Kidney Diseases. 2013;61(1):1-476.

8. Currie G, Delles C. Urinary Proteomics for Diagnosis and Monitoring of Diabetic Nephropathy. Current Diabetes Reports. 2016;16(11):1-104.

9. Colburn WA, Gruttola VG, Mets DL, et al. Biomarkers and surrogate endpoints: preferred definitions and conceptual framework. Clinical pharmacology and therapeutics. 2001;69(3):89-95.

10. Microvascular Complications and Foot Care, Diabetic Kidney Disease. American Diabetes Association. 2018;(1):S105-S119.

11. Levey AS, Stevens LA, Schmid CH, et al. CKD-EPI (Chronic Kidney Disease Epidemiology Collaboration). A new equation to estimate glomerular filtration rate. Annals of internal medicine. 2009;150(9):604-612.

12. Stevens LA, Coresh J, Feldman HI, et al. Evaluation of the Modification of Diet in Renal Disease Study Equation in a Large Diverse Population. Journal of the American Society of Nephrology. 2007;18(10):2749-2757.

13. Guidone C, Gniuli D, Castagneto-Gissey L, et al. Underestimation of urinary albumin to creatinine ratio in morbidly obese subjects due to high urinary creatinine excretion. Clinical Nutrition. 2012;31(2):212216.

14. Camargo EG, Soares AA, Detanico AB, et al. The Chronic Kidney Disease Epidemiology Collaboration (CKD-EPI) equation is less accurate in patients with Type 2 diabetes when compared with healthy individuals. Diabetic Medicine. 2011;28(1):90-95.

15. Perkins BA, Ficociello LH, Roshan B, et al. In patients with type 1 diabetes and new-onset microalbuminuria the development of advanced chronic kidney disease may not require progression to proteinuria. Kidney International. 2010;77(1):57-64.

16. Pavkov ME, Knowler WC, Lemley KV, et al. Early Renal Function Decline in Type 2 Diabetes. Clinical Journal of the American Society of Nephrology. 2012;7(1):78-84.

17. Mac Isaac RJ, Jerums G. Diabetic kidney disease with and without albuminuria. Current Opinion in Nephrology and Hypertension. 2011;20(3):246-257.

18. Ninomiya T, Perkovic V, Galan BE, et al. Albuminuria and Kidney Function Independently Predict Cardiovascular and Renal Outcomes in Diabetes. Journal of the American Society of Nephrology. 2009;20(8):1813-1821. 
19. Perkins BA, Ficociello LH, Silva KH, et al. Regression of Microalbuminuria in Type 1 Diabetes. New England Journal of Medicine. 2003;348(23):2285-2293.

20. Rossing P, Hougaard P, Parving HH. Progression of microalbuminuria in type 1 diabetes: Ten-year prospective observational study. Kidney International. 2005;68(4):1446-1450.

21. Schievink B, Mol PGM, Lambers Heerspink HJ. Surrogate endpoints in clinical trials of chronic kidney disease progression. Current Opinion in Nephrology and Hypertension. 2015;24(6):492-497.

22. Schutte E, Gansevoort RT, Benner J, et al. Will the future lie in multitude? A critical appraisal of biomarker panel studies on prediction of diabetic kidney disease progression. Nephrology Dialysis Transplantation. 2015;30(4):96-104.

23. Tsai PY, Chen SM, Chen HY, et al. Proteome analysis of altered proteins in streptozotocin-induced diabetic rat kidney using the fluorogenic derivatization-liquid chromatography-tandem mass spectrometry method. Biomedical Chromatography. 2012;27(3):382-389.

24. Betz BB, Jenks SJ, Cronshaw AD, et al. Urinary peptidomics in a rodent model of diabetic nephropathy highlights epidermal growth factor as a biomarker for renal deterioration in patients with type 2 diabetes. Kidney International. 2016;89(5):1125-1135.

25. Merchant ML, Perkins BA, Boratyn GM, et al. Urinary peptidome may predict renal function decline in type 1 diabetes and microalbuminuria. Journal of the American Society of Nephrology. 2009;20(9):2065-2074.

26. Good DM, Zürbig P, Argilés A, et al. Naturally occurring human urinary peptides for use in diagnosis of chronic kidney disease. Molecular \& cellular proteomics. 2010;9(11):2424-2437.

27. Zurbig P, Jerums G, Hovind P, et al. Urinary Proteomics for Early Diagnosis in Diabetic Nephropathy. Diabetes. 2012;61(12): 3304 3313.

28. Zurawska-Plaksej E, Lugowska A, Hetmańczyk K, et al. Proteins from the 18 glycosyl hydrolase family are associated with kidney dysfunction in patients with diabetes type 2. Biomarkers. 2015;20(1):52-57.

29. Mou X, Zhou DY, Ma JR, et al. Serum TGF- $\beta 1$ as a Biomarker for Type 2 Diabetic Nephropathy: A Meta-Analysis of Randomized Controlled Trials. PloS one. 2016;11(2):e0149513

30. Thongboonkerd V, Barati MT, Leish KR, et al. Alterations in the renal elastin-elastase system in type 1 diabetic nephropathy identified by proteomic analysis. Journal of the American Society of Nephrology. 2004;15(3):650-662.

31. Jin $\mathrm{J}, \mathrm{Ku} \mathrm{YH}, \mathrm{Kim} \mathrm{Y}$, et al. Differential proteome profiling using iTRAQ in microalbuminuric and normoalbuminuric type 2 diabetic patients. Experimental diabetes research. 2012.
32. Jiang H, Guan G, Zhang R, et al. Identification of urinary soluble $\mathrm{E}$-cadherin as a novel biomarker for diabetic nephropathy. Diabetes/ Metabolism Research and Reviews. 2009;25(3):232-241.

33. Bhensdadia NM, Hunt KJ, Lopes-Virella MF, et al. Veterans Affairs Diabetes Trial (VADT) study group. Urine haptoglobin levels predict early renal functional decline in patients with type 2 diabetes. Kidney International. 2013;83(6):1136-1143.

34. Wobeto VPA, Garcia PMD, Zaccariotto TR, et al. Haptoglobin polymorphism and diabetic nephropathy in Brazilian diabetic patients. Annals of Human Biology 2009;36(4):437-441.

35. Amor AJ, Canivell S, Oriola J, et al. Haptoglobin genotype and risk of diabetic nephropathy in patients with type 1 diabetes mellitus: a study on a Spanish population. Nefrologia publicacion oficial dela Sociedad Espanola Nefrologia. 2014;34(2):212-215.

36. Alpers CE, Hudkins KL. Mouse models of diabetic nephropathy. Current opinion in nephrology and hypertension. 2011;20(3):278284.

37. Kato M, Park JT, Natarajan R. Micro RNAs and the glomerulus. Experimental Cell Research. 2012;318(9):993-1000.

38. Ziyadeh FN, Sharma K. Overview: combating diabetic nephropathy Journal of the American Society of Nephrology. 2003;14(5):13551357.

39. Ambros V. The functions of animal micro RNAs. Nature. 2004;431(7006):350-355.

40. Bartel DP. Micro RNAs: Target Recognition and Regulatory Functions. Cell. 2009;136(2):215-233.

41. El-Samahy MH, Adly A, Elhenawy YI, et al. Urinary miRNA-377 and miRNA-216a as biomarkers of nephropathy and subclinical atherosclerotic risk in pediatric patients with type 1 diabetes. Journal of Diabetes and its Complications. 2018;32(2):185-192.

42. Zhang Z, Peng $\mathrm{H}$, Chen J, et al. MicroRNA-21 protects from mesangial cell proliferation induced by diabetic nephropathy in $\mathrm{db} / \mathrm{db}$ mice. FEBS Letters. 2009;583(12):2009-2014

43. LI JY, Yong TY, Michael MZ, et al. Review: The role of micro RNAs in kidney disease. Nephrology. 2010;15(6):599-608.

44. Kato M, Zhang J, Wang M, et al. MicroRNA-192 in diabetic kidney glomeruli and its function in TGF-beta-induced collagen expression via inhibition of E-box repressors. Proceedings of the National Academy of Sciences. 2007;104(9):3432-3437.

45. Ma X, Lu C, Lv C, et al. The Expression of miR-192 and Its Significance in Diabetic Nephropathy Patients with Different Urine Albumin Creatinine Ratio. Journal of Diabetes Research. 2016.

46. Deshpande SD, Putta S, Wang M, et al. Transforming growth factor- $\boldsymbol{\beta}$ induced cross talk between p53 and a micro RNA in the pathogenesis of diabetic nephropathy. Diabetes. 2013;62(9):3151-3162. 